\title{
Real-time quantitative PCR assay development and application for assessment of agricultural surface water and various fecal matter for prevalence of Aliarcobacter faecis and Aliarcobacter lanthieri
}

Mary G. Miltenburg ${ }^{1,2}$, Michel Cloutier ${ }^{1}$, Emilia Craiovan ${ }^{1}$, David R. Lapen ${ }^{1}$, Graham Wilkes ${ }^{1,3}$, Edward Topp ${ }^{4}$ and Izhar U. H. Khan ${ }^{1 *}$ (D)

\begin{abstract}
Background: Aliarcobacter faecis and Aliarcobacter lanthieri are recently identified as emerging human and animal pathogens. In this paper, we demonstrate the development and optimization of two direct DNA-based quantitative real-time PCR assays using species-specific oligonucleotide primer pairs derived from rpoB and gyrA genes for $A$. faecis and A. lanthieri, respectively. Initially, the specificity of primers and amplicon size of each target reference strain was verified and confirmed by melt curve analysis. Standard curves were developed with a minimum quantification limit of 100 cells $\mathrm{mL}^{-1}$ or $^{-1}$ obtained using known quantities of spiked A. faecis and A. lanthieri reference strains in autoclaved agricultural surface water and dairy cow manure samples.

Results: Each species-specific qPCR assay was validated and applied to determine the rate of prevalence and quantify the total number of cells of each target species in natural surface waters of an agriculturally-dominant and non-agricultural reference watershed. In addition, the prevalence and densities were determined for human and various animal (e.g., dogs, cats, dairy cow, and poultry) fecal samples. Overall, the prevalence of A. faecis for surface water and feces was 21 and 28\%, respectively. The maximum $A$. faecis concentration for water and feces was $2.3 \times$ $10^{7}$ cells $100 \mathrm{~mL}^{-1}$ and $1.2 \times 10^{7}$ cells $\mathrm{g}^{-1}$, respectively. A. lanthieri was detected at a lower frequency (2\%) with a maximum concentration in surface water of $4.2 \times 10^{5}$ cells $100 \mathrm{~mL}^{-1}$; fecal samples had a prevalence and maximum density of $10 \%$ and $2.0 \times 10^{6}$ cells $\mathrm{g}^{-1}$, respectively.

(Continued on next page)
\end{abstract}

\footnotetext{
* Correspondence: Izhar.Khan@canada.ca

'Ottawa Research and Development Centre (ORDC), Agriculture and Agri-Food Canada, 960 Carling Ave, Ottawa, Ontario K1A 0C6, Canada

Full list of author information is available at the end of the article
}

(C) Her Majesty the Queen in Right of Canada, as represented by the Minister of Agriculture and Agri-Food Canada 2020 Open Access This article is licensed under a Creative Commons Attribution 4.0 International License, which permits use, sharing, adaptation, distribution and reproduction in any medium or format, as long as you give appropriate credit to the original author(s) and the source, provide a link to the Creative Commons licence, and indicate if changes were made. The images or other third party material in this article are included in the article's Creative Commons licence, unless indicated otherwise in a credit line to the material. If material is not included in the article's Creative Commons licence and your intended use is not permitted by statutory regulation or exceeds the permitted use, you will need to obtain permission directly from the copyright holder. To view a copy of this licence, visit http://creativecommons.org/licenses/by/4.0/. The Creative Commons Public Domain Dedication waiver (http://creativecommons.org/publicdomain/zero/1.0/) applies to the data made available in this article, unless otherwise stated in a credit line to the data. 
(Continued from previous page)

Conclusions: The results indicate that the occurrence of these species in agricultural surface water is potentially due to fecal contamination of water from livestock, human, or wildlife as both species were detected in fecal samples. The new real-time qPCR assays can facilitate rapid and accurate detection in $<3 \mathrm{~h}$ to quantify total numbers of $A$. faecis and $A$. lanthieri cells present in various complex environmental samples.

Keywords: qPCR, Aliarcobacter faecis, Aliarcobacter lanthieri, Agricultural watershed, Surface water, Assay, Fecal matter

\section{Highlights}

1. Novel qPCR assays for A. faecis and A. lanthieri

2. Identifying prevalence of Aliarcobacter spp. in environmental samples

3. Quantitation of A. faecis and A. lanthieri in water and feces

\section{Background}

Recently, the Arcobacter genus has been reclassified and divided into seven new genera where novel genus Aliarcobacter consists of eight species [1]. Of these Aliarcobacter species, A. faecis and A. lanthieri, isolated from human and animal fecal sources, have been identified as pathogenic bacteria [2-4]. Some of the most prevalent Aliarcobacter species including A. butzleri, A. cryaerophilus, and A. skirrowii have been identified as causative agents for human (e.g., gastroenteritis, bacteremia, and sepsis) and animal (e.g., mastitis, diarrhea, abortion, and reproductive disorders) infections [5]. These species have also been isolated from a variety of food products, including chicken, beef, pork, and shellfish as well as various aquatic sources [6-10] and pose an important risk for human infection from contamination of water and food resulting from a variety of sources including livestock and poultry wastes, agricultural runoff, septic leakages, and direct or indirect inputs of wildlife fecal matter [11-14]. Therefore, there is a need to determine the degree of prevalence and identify potential sources of contamination of $A$. faecis and A. lanthieri in various fecal and aquatic niches.

Conventional culture-based methods for the identification and quantification of bacterial species from potentially contaminated environmental samples are traditionally slow and cannot be used for the identification of genus Aliarcobacter to the species-level [15]. Biochemical tests for the correct differentiation of Aliarcobacter spp., including A. faecis and A. lanthieri are difficult to differentiate using fastidious selective growth conditions, especially when they are present in low concentrations and in competition with other contaminants $[5,16]$. Moreover, these methods may not be accurate enough to measure cell viability, as cells may enter into viable but non-culturable (VBNC) or non-viable and nonculturable (NVNC) states. For many situations, it is important to use techniques that can quantify the total number of cells, including VBNC and NVNC states, more accurately in various complex environmental niches. Non-viable or nonculturable cells of Gram-negative bacteria can potentially contaminate water by producing virulence-associated factors and toxins that can pose health risks to humans $[17,18]$.

Real-time quantitative PCR (qPCR) assays have provided more rapid and robust tools to detect and quantify Aliarcobacter spp. in pure culture, fecal, hide, food, and complex environmental samples [19-22]. None of these developed real-time qPCR assays were capable of differentiating and quantifying $A$. faecis and A. lanthieri directly from environmental matrices, partly because of their unknown status and/or low abundance in these niches.

Therefore, it is necessary to develop fast and accurate methods for detecting these species in complex environmental matrices, since conventional methods are not always accurate measures for recovery and may fail to detect these species when prevalent at low concentrations and when competing with other Aliarcobacter spp. The main objectives of this study were to: i) develop and optimize species-specific direct real-time qPCR assays to quantitatively detect $A$. faecis and A. lanthieri in environmental niches; and ii) validate and apply these qPCR assays to detect, quantify, and assess the prevalence of $A$. faecis and A. lanthieri in agricultural surface water and fecal samples from human and animal sources.

\section{Results \\ Optimization of species-specific real-time qPCR assays and development of standard curves}

Two novel real-time PCR assays were developed and optimized using A. faecis LMG 28519 and A. lanthieri LMG 28516 reference strains. The assays were further validated by applying to the field isolates of each target species (A. faecis: $n=29$; and A. lanthieri: $n=10$ ). The primers specifically amplified to their target sequences with expected melting peaks of $74{ }^{\circ} \mathrm{C}$ for $A$. lanthieri and $79^{\circ} \mathrm{C}$ for A. faecis (Fig. $1 \mathrm{~A}$ and $\mathrm{B}$ ) and typical amplicon sizes $152 \mathrm{bp}$ and $72 \mathrm{bp}$, respectively (Figure S1A and B). Moreover, no amplification signals were observed for any other Aliarcobacter spp. or other bacterial reference species and strains that could potentially occur in water and fecal matter (Table 1). 

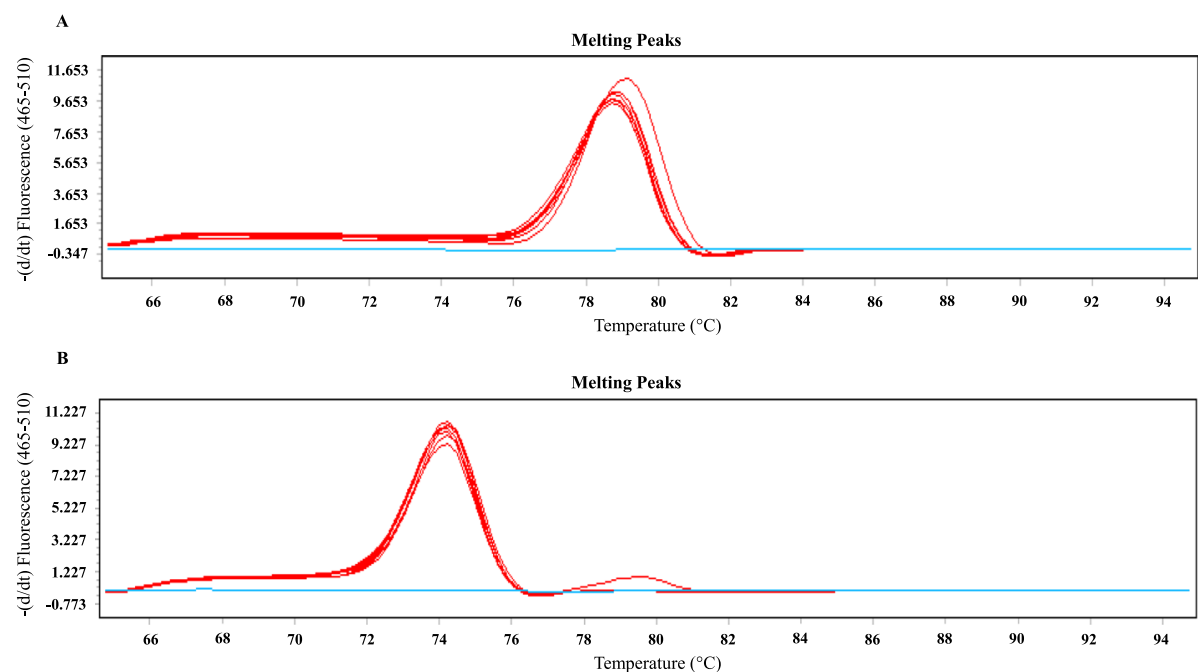

Fig. 1 The melting curves generated for the typical amplicons showed specific relative intensity of $79^{\circ} \mathrm{C}$ for $\mathrm{A}$. faecis (rpoB gene) (Panel $\left.\mathbf{A}\right)$ and $74^{\circ} \mathrm{C}$ for A. lanthieri (gyrA gene) (Panel B) reference strains and field isolates against -ve controls

The limit of detection for quantitative analysis of each optimized real-time PCR assay was determined by developing standard curves of reference strains of $A$. faecis and $A$. lanthieri DNA templates extracted from spiked water and dairy cow manure samples, in units of number of cells $\mathrm{mL}^{-1}$ (Fig. 2A and B) and cells $\mathrm{g}^{-1}$ (Fig. 3A and $\mathrm{B})$. Although a minimum of 10 cells $\mathrm{mL}^{-1}$ or 10 cells $\mathrm{g}^{-1}$ were also used for the quantitative assay, amplification was observed at $\geq 40 \mathrm{Cq}$ value; therefore, $\mathrm{Cq}$ value $\geq 42$ thresholds were considered as negative or indeterminate.

qPCR assay validation and application for detection and quantitation of $A$. faecis and $A$. lanthieri in agricultural surface water and fecal sources

The qPCR assays were further validated and applied by analysing a total of 804 environmental (fecal and surface water) samples. Of the total 588 agricultural surface water samples, A. faecis was detected at a frequency of $21 \%(n=124)$, while $A$. lanthieri $(n=13)$ was only detected in $2 \%$ of samples. Similarly, of the total 216 (human, $n=19$; animals, $n=197$ ) fecal samples, A. faecis $(n=61)$ was detected more commonly (28\%) than $A$. lanthieri (10\%; $n=22)$.

Further comparative analyses showed that the rate of A. faecis prevalence was significantly higher $(p<0.05)$ than $A$. lanthieri in agricultural sites (Table 2). Interestingly, only A. faecis (19\% frequency), not A. lanthieri, was detected at the reference sampling site 24 (Table 2). Overall, the frequency of co-occurrence of these two target species was low and observed in only one single surface water sample, which was collected from an agricultural drainage ditch with upstream proximity to dairy livestock operations. Moreover, among the 11 agriculturally impacted sites, A. faecis was detected at a significantly $(p<0.05)$ higher frequency $(>20 \%)$ at sampling sites $5,6,10,18$ and 20 as compared to sampling sites 1 , $8,9,19,21$ and $253(<20 \%)$. There was no significance $(p>0.05)$ difference in the occurrence of $A$. lanthieri among the sites.

Of the total 216 fecal samples collected from human and various animal fecal sources, $28 \%(n=61)$ and $10 \%(n=22)$ samples were positive for $A$. faecis and $A$. lanthieri, respectively. Among these different fecal samples, A. faecis was detected at higher frequencies in human, cat, cow, dog, and pig, compared to A. lanthieri which was detected at lower frequency (Table 3 ). Interestingly, only one fecal sample from chicken was positive for $A$. lanthieri whereas one fecal sample from sheep was positive for $A$. faecis . On the other hand, duck, goat, and pony fecal samples were negative for both target species. Similar to the water samples, a low frequency of co-occurrence of both species in only four (cow: $n=2$; human: $n=1$; pig: $n=1$ ) fecal samples was observed. Additional comparative analysis showed, overall, no significant $(p>0.05)$ difference in the rate of prevalence of $A$. faecis and $A$. lanthieri between human and animal fecal samples was observed. Similarly, no significant difference between the rate of prevalence of $A$. faecis and $A$. lanthieri was found among human, cat, and $\operatorname{dog}$ fecal samples. However, a significantly higher frequency of occurrence ( $p<$ $0.05)$ of $A$. faecis than $A$. lanthieri was observed between cow and pig fecal samples.

Furthermore, the total cell concentrations of the $124 \mathrm{~A}$. faecis and $13 \mathrm{~A}$. lanthieri positive surface water samples ranged from $2.57 \times 10^{3}$ to $2.29 \times 10^{7}$ cells $100 \mathrm{~mL}^{-1}$ and $1.15 \times 10^{4}$ to $4.16 \times 10^{5}$ cells $100 \mathrm{~mL}^{-1}$, respectively. 
Table 1 List of reference strains of target and other bacterial species and strains used in this study

\begin{tabular}{|c|c|c|c|}
\hline Sr. \# & Species & Source & Strain ID \\
\hline 1 & Haloarcobacter (Arcobacter) bivalviorum & Shellfish & LMG 26154 \\
\hline 2 & Aliarcobacter (Arcobacter) butzleri & Human diarrheic stool & ATCC 49616 \\
\hline 3 & A. cryaerophilus & Bovine aborted fetus & NCTC 11885 \\
\hline 4 & A. lanthieri & Pig manure & LMG 28516 \\
\hline 5 & A. faecis & Human waste & LMG 28519 \\
\hline 6 & A. skirrowii & Lamb feces & ATCC 51322 \\
\hline 7 & A. thereius & Organs of aborted porcine & LMG 24486 \\
\hline 8 & A. trophiarum & Feces of fattening pigs & LMG 25534 \\
\hline 9 & A. cibarius & Broiler carcasses & LMG 21996 \\
\hline 10 & Pseudoarcobacter (Arcobacter) defluvii & Sewage & LMG 25694 \\
\hline 11 & P. ellisii & Mussels & LMG 26115 \\
\hline 12 & P. venerupis & Shellfish & LMG 26156 \\
\hline 13 & Malacobacter (Arcobacter) halophilus & Hypersaline lagoon & ATCC BAA-1022 \\
\hline 14 & M. marinus & Mix seawater, starfish and seaweed & LMG 25770 \\
\hline 15 & M. molluscorum & Mussels and oysters & LMG 25693 \\
\hline 16 & M. mytili & Mussels & LMG 24559 \\
\hline 17 & Arcobacter nitrofigilis & Roots & ATCC 33309 \\
\hline 18 & Aeromonas allosaccharophila & Diseased elvers & ATCC 51208 \\
\hline 19 & A. bestiarum & Infected fish & ATCC 51108 \\
\hline 20 & A. caviae & Epizootic of young guinea pigs & ATCC 15468 \\
\hline 21 & A. hydrophila & Ditch water & ATCC 13444 \\
\hline 22 & A. jandaei & Human feces & ATCC 49568 \\
\hline 23 & A. media & Marine fish & CDC 0435-84 \\
\hline 24 & A. popoffi & Drinking water production plant & BAA-243 \\
\hline 25 & A. salmonicida & Freshwater & CDC 0434-84 \\
\hline 26 & A. schubertii & Skin & ATCC 43700 \\
\hline 27 & A. sobria & Sludge & ATCC 35994 \\
\hline 28 & A. trota & Human feces & ATCC 49658 \\
\hline 29 & A. veronii & Red-leg frog & ATCC 9071 \\
\hline 30 & A. bv. veronii & Amputation Wound & ATCC 35625 \\
\hline 31 & Campylobacter jejuni & Human feces & ATCC 33291 \\
\hline 32 & C. jejuni & Human feces & ATCC 29428 \\
\hline 33 & C. jejuni & Human feces & ATCC 33291 \\
\hline 34 & C. jejuni & Human feces & ATCC 33292 \\
\hline 35 & C. jejuni subsp. doylei & Human feces & ATCC 49349 \\
\hline 36 & C. coli & Swine & ATCC 43136 \\
\hline 37 & C. coli & - & ATCC 49941 \\
\hline 38 & C. coli & Marmoset feces & ATCC 43478 \\
\hline 39 & C. lari & Human feces & ATCC 43675 \\
\hline 40 & C. helveticus & Cat & ATCC 51210 \\
\hline 41 & C. fetus subsp. fetus & Blood & ATCC 15296 \\
\hline 42 & C. hyointestinalis & Intestine of swine & ATCC 35217 \\
\hline 43 & C. lanienae & - & CCUG 44467 \\
\hline 44 & C. upsaliensis & Dog feces & ATCC 43954 \\
\hline
\end{tabular}


Table 1 List of reference strains of target and other bacterial species and strains used in this study (Continued)

\begin{tabular}{|c|c|c|c|}
\hline Sr. \# & Species & Source & Strain ID \\
\hline 45 & Escherichia coli O157:H7 & Environmental isolate & - \\
\hline 46 & E. coli & Canine & ATCC 35218 \\
\hline 47 & Enterococcus avium & Clinical isolate & ATCC 49464 \\
\hline 48 & E. casseliflavus & - & ATCC 700327 \\
\hline 49 & E. durans & Human feces & ATCC 6056 \\
\hline 50 & E. faecalis & Meat & ATCC 7080 \\
\hline 51 & E. faecium & Human feces & ATCC 6569 \\
\hline 52 & E. gallinarum & Chicken intestines & ATCC 49573 \\
\hline 53 & E. hirae & - & ATCC 8043 \\
\hline 54 & E. saccharolyticus & Straw bedding & ATCC 43076 \\
\hline 55 & Pseudomonas shigelloides & Environmental isolate & - \\
\hline 56 & Salmonella enterica subsp. arizonae & - & ATC C 13314 \\
\hline 57 & S. enterica subsp. diarizonae & - & ATCC 12325 \\
\hline 58 & S. enterica subsp. houtenae & - & ATCC 29932 \\
\hline 59 & Helicobacter pylori & Human gastric antrum & NCTC 11637 \\
\hline 60 & H. typhlonius & Human caecum & CCUG 48335 \\
\hline 61 & H. ganmani & Intestines of mice & CCUG 43526 \\
\hline 62 & H. marmotae & Woodchuck liver & CCUG 52419 \\
\hline 63 & H. cetorum & Baluga whale feces & ATCC BAA-429 \\
\hline 64 & Klebsiella pneumoniae & Human serotype 3 & ATCC 13883 \\
\hline 65 & Staphylococcus aureus & Clinical isolate & ATCC 25923 \\
\hline 66 & S. epidermidis & Clinical isolate & ATCC 12228 \\
\hline 67 & Streptococcus pyogenes & Clinical isolate & ATCC 19615 \\
\hline
\end{tabular}

However, the $112 \mathrm{~A}$. faecis positive surface water samples gave $10^{3}$ to $10^{5}$ cells $100 \mathrm{~mL}^{-1}$, where only 12 of the positive samples had high concentrations $\left(10^{6}\right.$ to $10^{7}$ cells 100 $\mathrm{mL}^{-1}$ ) compared to 13 A. lanthieri positive samples that had $10^{4}$ to $10^{5}$ cells $100 \mathrm{~mL}^{-1}$. Two agricultural sampling sites ( 1 and 8$)$ had similar maximal levels of $A$. faecis cell concentrations $\left(1.9 \times 10^{7}\right.$ and $\left.2.3 \times 10^{7} 100 \mathrm{~mL}^{-1}\right)$ (Fig. 4). Although $A$. lanthieri was not detected in all agricultural sites, a similar average level $\left(1 \times 10^{5}\right.$ cells $\left.100 \mathrm{~mL}^{-1}\right)$ of cell concentrations was observed in sampling sites $1,6,9,18$, 20, 21, and 253. The cell concentrations of A. lanthieri were lower than A. faecis across all sites (Fig. 4). Results were further analyzed across sample sites: of the top $5 \%$ non-zero quantitative data from sites 1,8 , and $9,1 \%$ of samples showed the cell concentrations above $4.1 \times 10^{5}, 2.1 \times 10^{5}$, and $1.2 \times 10^{5}$ cells $100 \mathrm{~mL}^{-1}$ of $A$. faecis as compared to $A$. lanthieri where $1 \%$ of samples of site 1 had cell concentration above $1.2 \times 10^{4}$ cells $100 \mathrm{~mL}^{-1}$.

The cell concentrations of 61 A. faecis and 22 A. lanthieri positive fecal samples ranged from $1.4 \times 10^{0}$ to $1.2 \times 10^{7}$ cells $\mathrm{g}^{-1}$ and $3.8 \times 10^{1}$ to $2.0 \times 10^{6}$ cells $\mathrm{g}^{-1}$, respectively. Of the total 83 positive fecal samples for both species, 45 (54\%) A. faecis and 21 (25\%) A. lanthieri positive samples had cell concentration ranging from $10^{3}$ to $10^{5}$ cells $\mathrm{g}^{-1}$, while six
(10\%) A. faecis and one (4\%) A. lanthieri positive samples had higher cell concentrations in the range of $10^{6}$ and $10^{7}$ cells $\mathrm{g}^{-1}$. When examining cell concentrations further across each fecal source, the highest average cell concentrations of $A$. faecis was found in human $\left(2.3 \times 10^{6}\right.$ cells g $\left.{ }^{-1}\right)$, cow $\left(7.1 \times 10^{5}\right.$ cells g $\left.^{-1}\right)$, and sheep $\left(2.4 \times 10^{5}\right.$ cells $\left.\mathrm{g}^{-1}\right)$ compared to $A$. lanthieri where highest average levels were found in chicken $\left(3.4 \times 10^{5}\right.$ cell g$\left.^{-1}\right)$ and pig $\left(2.7 \times 10^{5}\right.$ cells $\left.\mathrm{g}^{-1}\right)$ fecal samples (Fig. 5). However, the highest cell concentration of $A$. faecis was observed in human $\left(1.2 \times 10^{7}\right.$ cells g $\left.{ }^{-1}\right)$ and cow $\left(3.3 \times 10^{6}\right.$ cells g $\left.{ }^{-1}\right)$, while $A$. lanthieri had the highest cell concentrations in pig $\left(2.0 \times 10^{6}\right.$ cells $\left.\mathrm{g}^{-1}\right)$ and cow $\left(7.8 \times 10^{5}\right.$ cells $\left.\mathrm{g}^{-1}\right)$ fecal samples. However, fecal samples from dog had the lowest cell concentrations for both $A$. faecis $\left(4.8 \times 10^{2}\right.$ cells $\left.\mathrm{g}^{-1}\right)$ and $A$. lanthieri $\left(3.8 \times 10^{1}\right.$ cells $\mathrm{g}^{-1}$ ), respectively. Overall, of the $10 \%$ non-zero quantitative data, only $1 \% A$. faecis and $A$. lanthieri positive samples had cell concentration above $2.9 \times 10^{6}$ and $7.1 \times 10^{5}$ cells $\mathrm{g}^{-1}$, respectively.

\section{Discussion}

Conventional culture-based multiplex PCR assays for the detection of $A$. faecis and A. lanthieri, along with four other closely related Aliarcobacter spp., were developed by Khan et al. [15]. In the present study, we further 


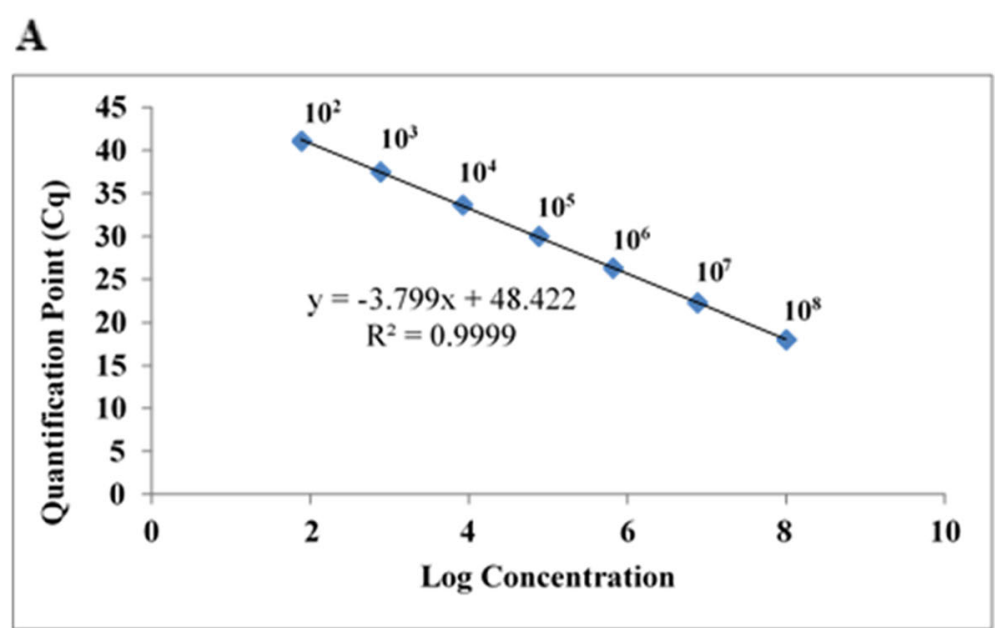

B

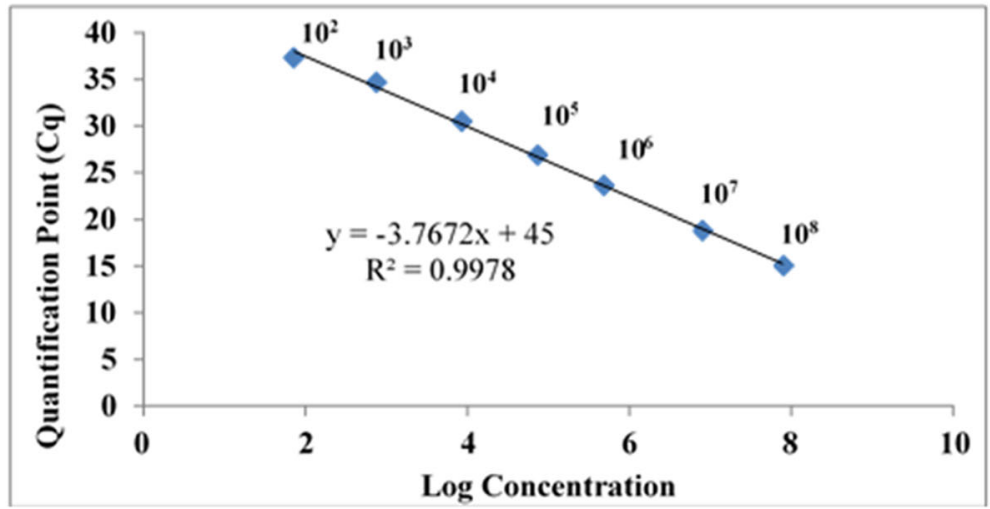

Fig. 2 Real-time GPCR-based standard curves developed for (Panel A) A. faecis and (Panel B) A. lanthieri from 10-fold serially diluted spiked cells (from $10^{2}$ to $10^{8} \mathrm{~mL}^{-1}$ ) in autoclaved agricultral surface water using species-specific qPCR assays. Each point representing the result of triplicate amplification of each dilution. The coefficients of determination $R^{2}$ and the slopes of each regression curves are indicated. The standard curves obtained by correlation of the Quantification Cycle (Cq) values and $\log _{10}$ cell number from the amplification plot

established species-specific direct DNA-based realtime quantitative PCR assays to improve the detection method for rapid identification and quantification of total number of (viable and non-viable) cells of $A$. faecis and $A$. lanthieri in surface water and fecal samples. Each species-specific qPCR assay is rapid, sensitive, and reliable for quantitative analysis of $A$. faecis and $A$. lanthieri DNA. The assay has a reproducible detection limit per reaction with linear amplification over a wide range of seven to eight orders of magnitude. GPCR assays are less time- and labor-intensive than culture-based methods, and have minimum potential for cross-contamination; therefore, the assays developed here are more robust and useful in diagnostic and analytical settings, especially when the cells of the target species are present at low concentrations $[23,24]$. The other advantage is that these assays do not require post-PCR confirmation, and possess the ability to provide quick results which are more desirable for high-throughput studies [25, 26]. In addition, the fluorescent dye SYBR Green was used in the developed assays, which is more cost-effective than fluorogenic probes. qPCR assays can also detect and quantify total (viable and non-viable) number of cells, which is important as the non-viable cells can generate human immunological responses despite these cells being incapable of causing infection. Therefore, the present qPCR assays we have developed allow quantitative detection of these species from complex environmental samples even when they are present at low levels.

To validate the newly developed assays, this study analyzed 588 water samples from an agriculturally dominated watershed and 216 samples from various fecal sources, and A. lanthieri and A. faecis were detected and quantified. Overall, we found that $A$. faecis was more 


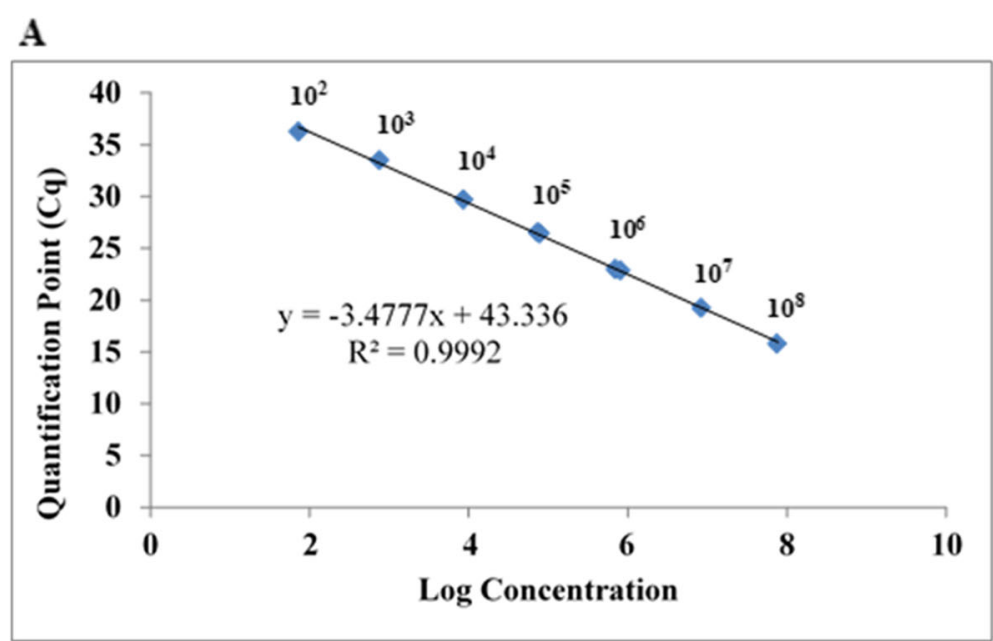

B

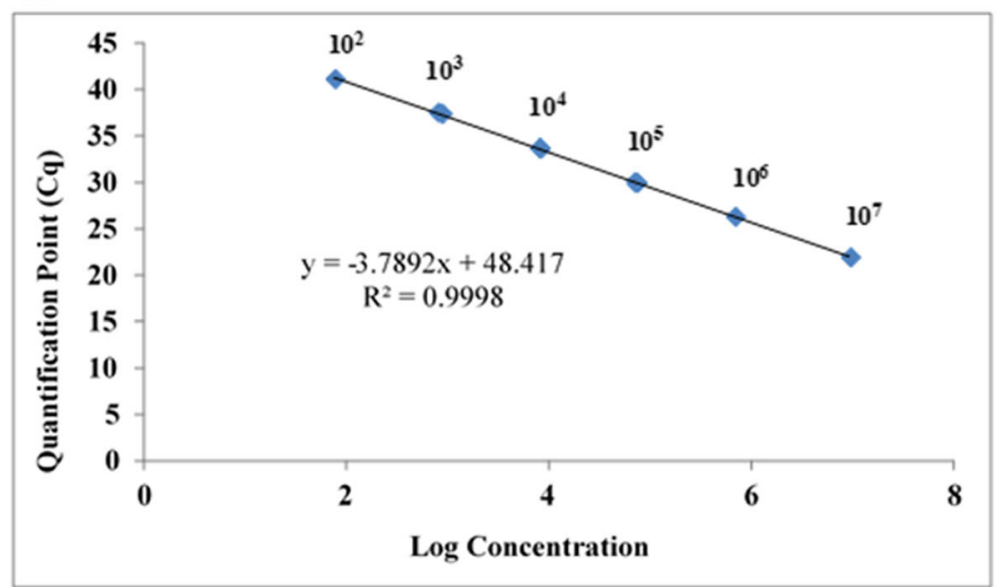

Fig. 3 Standard curves developed from DNA extracted from 10-fold serially diluted spiked cells of A. faecis (Panel A) (ranging from $10^{2}$ to $10^{8} \mathrm{~g}^{-1}$ ) and A. lanthieri (Panel B) (ranging from $10^{2}$ to $10^{7} \mathrm{~g}^{-1}$ ) in cow manure using species-specific qPCR assays. The standard curves obtained from amplification plot by correlation of the Quantification Cycle (Cq) cycle values and number of cells $\mathrm{g}^{-1}$ of feces. Each point is representing the result of duplicate amplification of each dilution where the correlation coefficients $R^{2}$ and the slopes of the regression curve are shown

Table 2 Total number (588) of surface water samples collected from the South Nation River watershed tested for detection and prevalence of $A$. faecis and A. lanthieri

\begin{tabular}{llll}
\hline Sampling sites & Total samples & No. (\%) of $\boldsymbol{A}$. faecis & No. (\%) of $\boldsymbol{A}$. lanthieri \\
\hline 1 & 30 & $5(17)$ & $1(3)$ \\
5 & 76 & $19(25)$ & 0 \\
6 & 76 & $24(32)$ & $1(1)$ \\
8 & 34 & $3(9)$ & 0 \\
9 & 33 & $3(9)$ & $2(6)$ \\
10 & 42 & $12(29)$ & 0 \\
18 & 75 & $19(25)$ & $4(5)$ \\
19 & 28 & $2(7)$ & 0 \\
20 & 67 & $14(21)$ & $1(1)$ \\
21 & 26 & $4(15)$ & $3(12)$ \\
\\
253 & 27 & $5(19)$ & $1(4)$ \\
\hline
\end{tabular}


Table 3 Total number (216) of human and animal fecal samples tested and positive for A. faecis (61) and A. lanthieri (22) using species-specific qPCR assays

\begin{tabular}{|c|c|c|c|}
\hline Fecal Sources & Total samples & No. (\%) of $\boldsymbol{A}$. faecis & No. (\%) of $\boldsymbol{A}$. lanthieri \\
\hline Human & 19 & $6(31)$ & $1(5)$ \\
\hline Cat & 20 & $4(20)$ & $1(5)$ \\
\hline Chicken & 8 & 0 & $1(13)$ \\
\hline Cow & 68 & $14(21)$ & $5(7)$ \\
\hline Dog & 18 & $2(11)$ & $1(6)$ \\
\hline Duck & 1 & 0 & 0 \\
\hline Goat & 4 & 0 & 0 \\
\hline Pig & 75 & $34(45)$ & $13(17)$ \\
\hline Pony & 2 & 0 & 0 \\
\hline Sheep & 1 & $1(100)$ & 0 \\
\hline
\end{tabular}

prevalent and occurred at higher levels than A. lanthieri in both fecal and water samples. Of the SNR water sites sampled, sites 1, 8, and 9 had significantly higher levels of $A$. faecis compared to sites 1 and 18 where higher relative levels of $A$. lanthieri were detected. Site 1, a drinking water intake source site, and site 8 are located on the main South Nation River stem, compared to sites 9 and 18 which are located on small stream orders that are closer to livestock operations. Although occurrence of $A$. lanthieri was not significantly different across the water sampling sites, it was most prevalent at site 21 , a small agricultural drainage ditch [27] where potential fecal inputs from adjacent farm lands and wildlife can occur readily due to tile drainage and surface runoff [28].

Levican et al. [29] found that cell counts for adhesion and invasion of different Aliarcobacter spp. were possible above the limits of $1.7 \times 10^{4} \mathrm{CFU} \mathrm{mL}^{-1}$ and $1.7 \times$ $10^{2} \mathrm{CFU} \mathrm{mL}^{-1}$, respectively. The cell concentrations of
A. lanthieri and $A$. faecis that we detected here ranged as high as $10^{7}$ cells $100 \mathrm{~mL}^{-1}$. Our findings are in congruence with a previous study [30] where a comparable range of concentration $\left(2.0 \times 10^{5}\right.$ to $1.2 \times 10^{9}$ cells 100 $\mathrm{mL}^{-1}$ ) of Arcobacter spp. in various water sources was reported.

In order to compare the rate of prevalence of these species in agriculture and non-agricultural surface waters, site 24 was chosen as a reference site, as it is not impacted by any known direct anthropogenic activity [31]. However, A. faecis was detected at this site which suggests that there may be alternate sources of water contamination, possibly from wildlife. However, in previous studies human-specific bacterial markers were detected at site 24 [32, 33]. Throughout the sampling period, among agriculturally dominated SNR sites, $A$. faecis was most frequently detected at sites 5 , $6,10,18$, and 20 that have dairy operations in the upstream vicinity (Table 3 ). Additionally, A. lanthieri

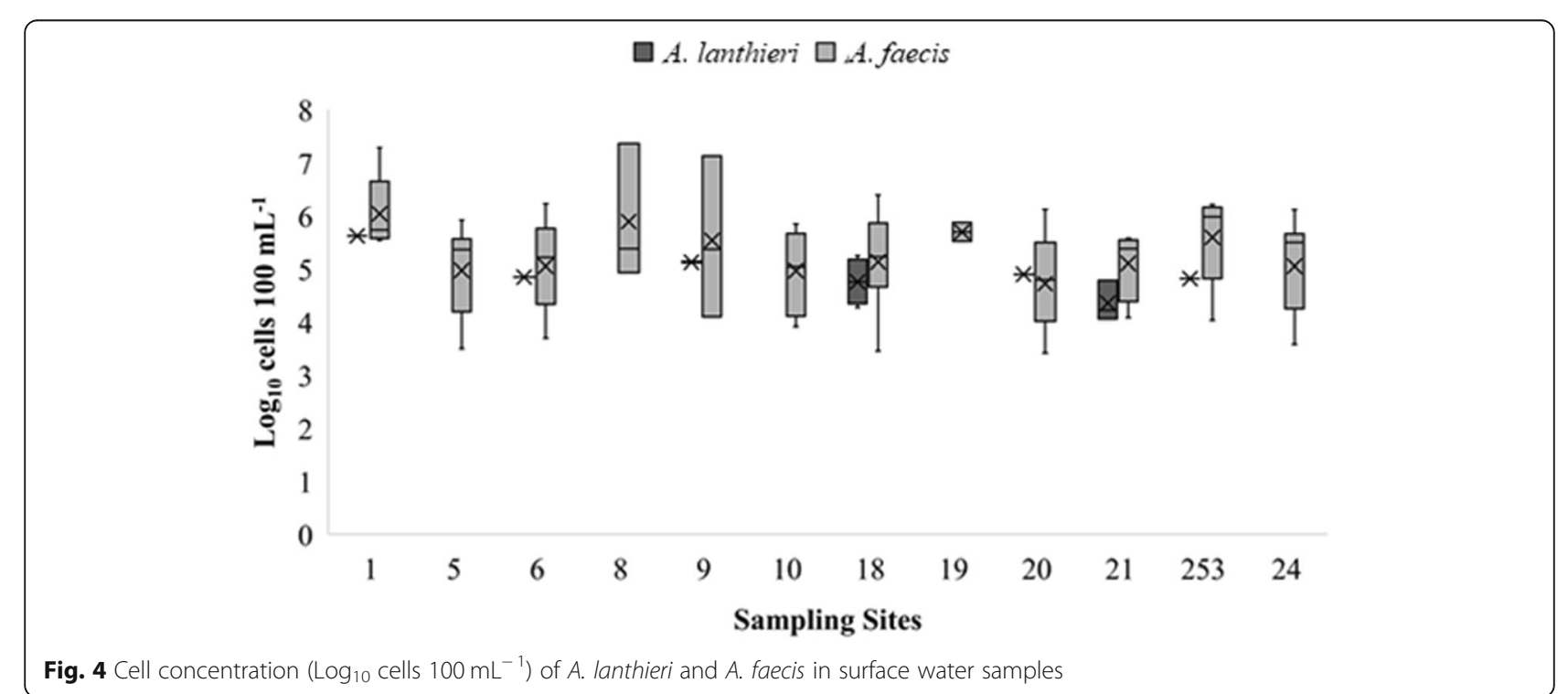




\section{A. lanthieri $\square$ A. faecis}

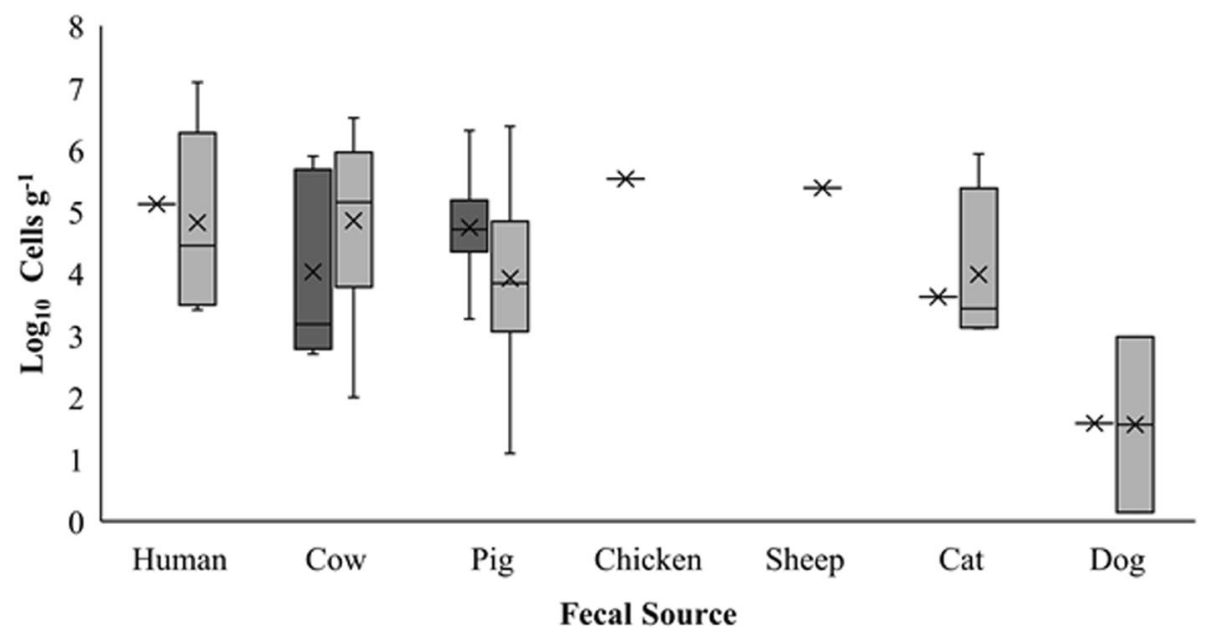

Fig. 5 Cell concentration ( $\log _{10}$ cells $\mathrm{g}^{-1}$ ) of A. lanthieri and A. faecis in humand and animal fecal samples

was most frequently detected at site 21 (Table 3), where dairy-based farming operations occur along the drainage ditch.

The prevalence of other microbial species in the SNR watershed has previously been examined, which add value in our capacity to detect $A$. lanthieri and $A$. faecis in the same study area. For example, Lyautey et al. [34] investigated the prevalence of Listeria monocytogenes, and also found that occurrence was associated with proximity to dairy farming operations. The authors found that sites 9 and 18 had the highest prevalence of L. monocytogenes. However, our results showed high frequency of $A$. faecis in site 18 compared to site 9. Frey et al. [35] detected Campylobacter spp. and Salmonella spp. at the same SNR watershed sites where cattle fecal markers were detected. A. lanthieri and A. faecis were originally isolated from human and fecal sources [4,5], and in this study both species were detected in human and livestock feces, as well as in agricultural surface water. This strongly indicates that contamination of water by fecal matter from livestock, particularly cattle, could be linked to the prevalence of $A$. lanthieri and A. faecis.

\section{Conclusions}

The qPCR assays designed here can accurately detect the prevalence and quantify the total number of cells of A. faecis and A. lanthieri in complex environmental niches. It is critical to develop alternative methods other than the widely-used culture-based techniques for the detection of gram-negative bacteria in environmental or clinical samples, as the presence of virulence, antibiotic resistance and toxin (VAT) genes can still pose a health risk even when cells are in a non-viable state. The study results suggest that routine quantitative testing of water sources for microbial contamination is important, especially in areas such as agricultural and urban communities where fecal contamination risks are higher. The developed assays could, therefore, provide rapid DNAbased tools for early and reliable detection of target species in field samples, which would help in improving water quality and intervention for reducing and eliminating the risk of contamination of $A$. faecis and $A$. lanthieri in aquatic sources.

\section{Methods \\ qPCR assay development and optimization Bacterial species and culture conditions}

For testing the specificity and sensitivity of primers and real-time qPCR assays for the detection and identification of $A$. faecis and A. lanthieri, two reference strains of A. faecis LMG 28519 and A. lanthieri LMG 28516, were used as positive controls (Table 1). Six other Aliarcobacter spp., nine species from genus Arcobacter, Haloarcobacter, Malacobacter and Pseudoarcobacter, and 50 other bacterial reference species and strains were used as negative controls (Table 1). In addition to the two LMG strains above, 29 A. faecis and 10 A. lanthieri cultures of our lab collection, isolated from various human and animal fecal and water samples, were used as positive controls. All control reference strains were grown on selective media according to appropriate aerobic and microaerophilic culture conditions. A. faecis and $A$. lanthieri strains were grown in Arcobacter media broth and incubated at $30^{\circ} \mathrm{C}$ under microaerophilic $\left(85 \% \mathrm{~N}_{2}\right.$, $10 \% \mathrm{CO}_{2}$ and $5 \% \mathrm{O}_{2}$ ) conditions with continuous shaking at $125 \mathrm{rpm}$. 


\section{DNA extraction from pure cultures of reference strains and field isolates}

The DNA from pure cultures of reference strains and field isolates was extracted using a boiling method [36] where a single colony was suspended in $75 \mu \mathrm{L}$ TE $(10$ $\mathrm{mM}$ Tris- $\mathrm{HCl}, 1 \mathrm{mM}$ EDTA, pH 8.0) buffer, boiled for $10 \mathrm{~min}$ and centrifuged. The supernatant containing DNA was quantified using a Qubit 3.0 fluorometer (Thermo Fisher Scientific, Waltham, MA, USA), transferred to a sterile tube, and stored at $-20{ }^{\circ} \mathrm{C}$ for further PCR analysis.

\section{Spiked assay for standard curve development and quantitation}

A spiking experiment was carried out to develop standard curves using A. faecis LMG 28519 and A. lanthieri LMG 28516 reference strains to assess the purity of nucleic acid in terms of yield, concentration, reproducibility and removal of potential PCR-inhibitory compounds. The experiment also helped to quantify and measure the sensitivity (least number of cells $\mathrm{mL}^{-1}$ ) of the qPCR assays. A. faecis and A. lanthieri cells were grown under microaerophilic conditions as described above. The cells were collected by centrifugation at room temperature and re-suspended in $1 \mathrm{~mL}$ TE buffer. The cell concentration $\mathrm{mL}^{-1}$ of each target species was measured on modified Arcobacter Agar Medium (m-AAM; Oxoid) containing selective antimicrobial agents (cefoperazone, amphotericin $\mathrm{B}$, and teicoplanin) and incubated under conditions as described above. The known quantity of $A$. faecis or $A$. lanthieri reference strain cells $\left(10^{8}\right.$ cells $\left.\mathrm{mL}^{-1}\right)$ was then simultaneously spiked and serially (10-fold) diluted from $10^{8}$ to $10^{1}$ cells $\mathrm{mL}^{-1}$ in autoclaved agricultural watershed water and cow manure samples. Each spiked water sample with known cell concentration was filtered through a $0.22 \mu \mathrm{m}$ sterile nitrocellulose filter.

Total genomic DNA was extracted from each spiked filter and $0.5 \mathrm{~g}$ manure sample with known cell concentration using DNeasy PowerSoil Kit (Qiagen; formerly MoBio PowerSoil DNA Isolation Kit) following the manufacturer's instructions. The purity and concentration of DNA was measured by Qubit 3.0 fluorometer and 1\% agarose gel electrophoresis using $1 \mathrm{X}$ TAE (0.04 M Trisacetate, 0.001 M EDTA, pH 7.8) buffer.

\section{Primer design and $q P C R$ assay conditions}

Real-time qPCR assays were developed and optimized for $A$. lanthieri by designing primer pairs from the variable region of the gyrase ( gyrA) gene. The primers were designed based on alignment analysis of gyr A gene sequences of Aliarcobacter and other reference species and strains belong to other genera available in the GenBank database. On the other hand, the real-time PCR assay for $A$. faecis was optimized by using primers from the rpoB gene encoding $\beta$-subunit of RNA polymerase previously designed by Khan et al. [15].

For each target species, a SYBR Green-based speciesspecific monoplex real-time qPCR amplification protocol was developed and optimized with a $20 \mu \mathrm{L}$ reaction mixture containing $10 \mu \mathrm{L}$ SsoAdvanced EvaGreen Supermix (Bio-Rad, Hercules, CA, USA), $10-50 \mathrm{ng} \mathrm{\mu L}^{-1}$ of purified DNA template of each target species, $0.01 \mathrm{uM}$ forward and reverse primers (Table 4), 5\% dimethyl sulfoxide (DMSO), and $0.1 \mathrm{uM}$ Bovine Serum Albumin (BSA). The final volume was adjusted to $20 \mu \mathrm{L}$ by adding sterile water.

The reactions were run on a Lightcycler ${ }^{\bullet} 480$ Instrument II (Roche, Indianapolis, IN, USA) with an initial denaturation at $98^{\circ} \mathrm{C}$ for $3 \mathrm{~min}$ followed by 50 cycles of denaturation at $98{ }^{\circ} \mathrm{C}$ for $15 \mathrm{~s}$, annealing temperatures of $58^{\circ} \mathrm{C}$ for A. faecis and $55^{\circ} \mathrm{C}$ for A. lanthieri for $30 \mathrm{~s}$, and extension at $72{ }^{\circ} \mathrm{C}$ for $30 \mathrm{~s}$. The amplified product obtained from each cell number was confirmed by melt curve analysis where the melting peak was 79 and $74{ }^{\circ} \mathrm{C}$ for $A$. faecis and A. lanthieri, respectively (Table 4). Due to expected small amplicon sizes, the amplified products were further confirmed on a $2 \%$ agarose gel matrix, stained (ethidium bromide $0.5 \mu \mathrm{g} \mathrm{mL}^{-1}$ ) and visualized on a UV transilluminator using an Alpha Imager (Fisher Scientific) gel documentation system.

\section{Validation and application of qPCR assays Study site description, and surface water and fecal sample collection}

The developed qPCR assays were further validated and applied to investigate the rate of prevalence and concentration of $A$. faecis or A. lanthieri cells in surface water and fecal samples. In order to assess the purity of total DNA in terms of removal of PCR inhibitors (such as humic acid, organic and inorganic compounds) and sensitivity of assays for quantitation of total number of cells,

Table 4 Oligonucleotide primer pairs and protocol used for optimized species-specific real-time qPCR-based assays

\begin{tabular}{|c|c|c|c|c|c|c|}
\hline Species & $\begin{array}{l}\text { Target } \\
\text { Gene }\end{array}$ & $\begin{array}{l}\text { Sequence } \\
5^{\prime}-3^{\prime}\end{array}$ & $\begin{array}{l}\text { Anealing Temp } \\
\left({ }^{\circ} \mathrm{C}\right)\end{array}$ & $\begin{array}{l}\text { Product Size } \\
\text { (bp) }\end{array}$ & $\begin{array}{l}\text { Melting Peak } \\
\left({ }^{\circ} \mathrm{C}\right)\end{array}$ & Reference \\
\hline A. faecis & rpoB & $\begin{array}{l}\text { Afae-F: GCT CCA GGA AGT ACA AAA GTA G } \\
\text { Afae-R: AGG CTA GCA GCT ACT CCC }\end{array}$ & 58.0 & 152 & 79 & Khan et al. 2017 [15] \\
\hline $\begin{array}{l}\text { A. } \\
\text { lanthieri }\end{array}$ & gyrA & $\begin{array}{l}\text { Alan-F: CTT GGT GAA TTG CTT GAT GCA A } \\
\text { Alan-R: CCA TTA AAT CAC TAG CTT CTG CT }\end{array}$ & 55.0 & 72 & 74 & This study \\
\hline
\end{tabular}


surface water samples were collected from the South Nation River (SNR) watershed, located near Ottawa, Ontario in eastern Canada [37]. The watershed covers an area of $\sim 3900 \mathrm{~km}^{2}$, of which approximately $60 \%$ is used for agricultural purposes, primarily related to dairy farming. A detailed description of the watershed and sampling sites have been previously reported by Wilkes et al. [37, 38] and Lapen et al. [39] (Table 2). For this study, a total of 12 sites of varying stream orders were selected for sampling, based on their proximity to agriculturallyimpacted areas. In addition, one site with no known upstream anthropogenic activity was selected as a reference site (Site 24; Edge et al.) [31] (Fig. 6). A total of 588 (from 2013 to 2018) surface water samples were collected on a bi-weekly basis between April and November. In addition, a total of 216 fecal samples from human $(n=19)$ and various animal $(n=197)$ sources including cat $(n=20)$; chicken $(n=8)$; cow $(n=68)$; dog $(n=18)$; duck $(n=1)$; goat $(n=4)$; pig $(n=75)$; pony $(n=2)$ and sheep $(n=1)$ were collected in the same region.

The surface water and fecal samples were collected in sterile polypropylene bottles and bags, placed in coolers and delivered to Agriculture and Agri-Food CanadaOttawa, Ontario Laboratory where the samples were processed within $24 \mathrm{~h}$ of their collection for microbiological analysis. Water samples were filtered through $0.22 \mu \mathrm{m}$ sterile nitrocellulose filters. The DNA from filters and fecal samples were extracted using DNeasy PowerSoil Kit and quantified by Qubit 3.0 fluorometer.

\section{Quantitation of A. faecis and A. lanthieri cell concentration in environmental sources}

The two optimized real-time $\mathrm{qPCR}$ assays described above were validated, using the developed standard curves, by detecting and quantifying the total number (viable and non-viable) of $A$. faecis and A. lanthieri cells $100 \mathrm{~mL}^{-1}$ from agricultural surface water and fecal samples. The specificity and quality of amplified products were confirmed by analyzing and comparing the melting curves to the standard melting peaks obtained for A. faecis and $A$. lanthieri amplicons. In addition, the amplification quality was also validated by agarose gel electrophoresis using 100 bp DNA size marker (Thermo Fisher Scientific) (Fig. S2A\&B). The gel was stained, visualized, and photographed as described in the preceding section.

\section{Data analysis}

McNemar Chi-square Contingency and Fisher's Exact tests were applied to compare the rate of prevalence and identify significant differences $(p<0.05)$ of $A$. faecis and $A$. lanthieri among different agricultural and non-agricultural sites, surface water and fecal samples using STATISTICA (StatSoft, Inc., 2013) [40].

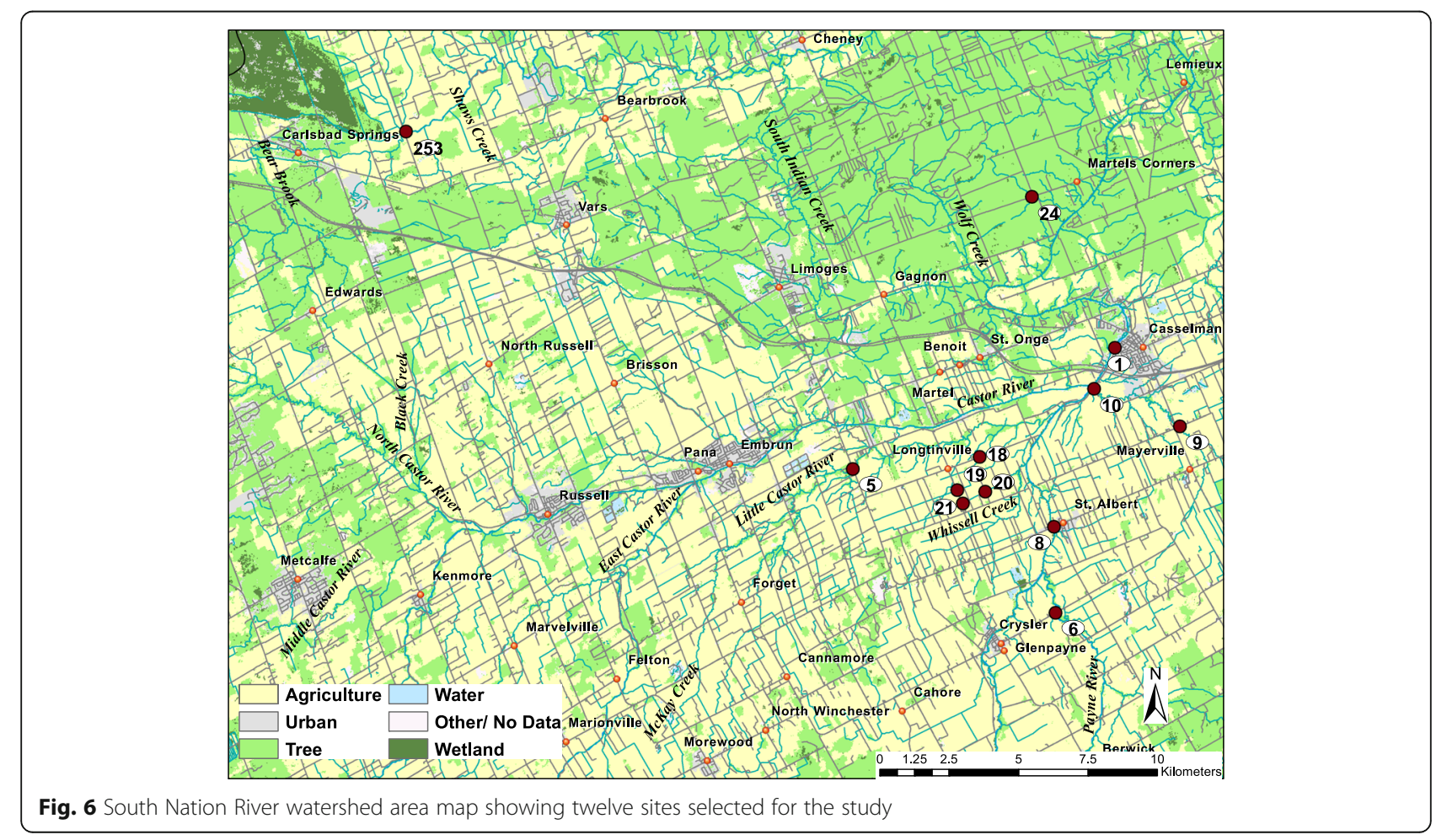




\section{Supplementary information}

Supplementary information accompanies this paper at https://doi.org/10. 1186/s12866-020-01826-3.

Additional file 1: Supplementary Figure 1A\&B. Real-time $q P C R$ amplified product confirmation on 2\% agarose gel for $A$. faecis LMG 28519 reference strain and field isolates (Panel $A$; Lanes 1-4) and A. lanthieri reference strain LMG 28516 and field isolates (Panel B; Lanes 1-4) with an expected 152 and 72 bp sizes, respectively. Lanes 5 and 11: A. butzleri, $A$. cryaerophilus, A. skirrowii, A. thereius, A. trophiarum, A. cibarius and no DNA template (PCR reaction mix) served as negative controls; M: 100 bp DNA size marker. Supplementary Figure 2A\&B. Real-time qPCR amplified product confirmation on $2 \%$ agarose gel showing positive and negative field samples for $A$. faecis (Panel A) and A. lanthieri (Panel B) with an expected 152 and 72 bp sizes, respectively. Lane 1: A. faecis and A. lanthieri reference strains served as positive controls; M: 100 bp DNA size marker.

\section{Abbreviations}

DMSO: Dimethyl sulfoxide; BSA: Bovine Serum Albumin; m-AAM: modified Arcobacter Agar Medium; SNR: South Nation River; gyrA: gyrase gene

\section{Acknowledgements}

We thank the field crew and co-op students Mark Libby, Linda Liu, Ozair Islam and Ferdinand Miranda for sample collection and lab assistance. We also thank farmers for their cooperation in accessing farms for water and fecal sample collection.

\section{Authors' contributions}

$\mathrm{MM}, \mathrm{MC}$, and IK conceived research project, performed sequence analyses and designed the experiments. MM, MC and IK designed primers and $\mathrm{QPCR}$ protocols, performed laboratory experiments, analyzed results and drafted manuscript. EC, GW, DL and ET coordinated in selecting field sampling sites and sample collection protocols as well as contributed in interpreting results data and editing manuscript. All authors reviewed, edited and approved the final manuscript.

\section{Funding}

The study funds were provided by Agriculture and Agri-Food Canada under project \#s: J-000157 and J-001012. The funding source was not involved in study design, sample collection, data analysis and interpretation.

\section{Availability of data and materials}

The data generated and analyzed in this study are available upon request.

\section{Ethics approval and consent to participate}

Not applicable.

\section{Consent for publication}

Not applicable.

\section{Competing interests}

Authors have no competing interest to report

\section{Author details}

Ottawa Research and Development Centre (ORDC), Agriculture and Agri-Food Canada, 960 Carling Ave, Ottawa, Ontario K1A 0C6, Canada. ${ }^{2}$ Canadian Food Inspection Agency (CFIA), Ottawa, ON, Canada. ${ }^{3}$ Natural Resources Canada, Ottawa, ON, Canada. ${ }^{4}$ London Research and Development Centre (LRDC), Agriculture and Agri-Food Canada, London, ON, Canada.

Received: 3 March 2020 Accepted: 18 May 2020

Published online: 16 June 2020

\section{References}

1. Pérez-Cataluña A, Salas-Massó N, Diéguez AL, Balboa S, Lema A, Romalde JL, Figueras MJ. Revisiting the taxonomy of the genus Arcobacter: getting order from the chaos. Front Microbiol. 2018;9:2077.
2. Whiteduck-Léveillée K, Whiteduck-Léveillée J, Cloutier M, Tambong JT, Xu R, Topp E, Khan IUH. Arcobacter lanthieri sp. nov., isolated from pig and dairy cattle manure. Int J Syst Evol Microbiol. 2015;65:2709-16.

3. Whiteduck-Léveillée K, Whiteduck-Léveillée J, Cloutier M, Tambong JT, Xu R, Topp E, Khan IUH. Identification, characterization and description of Arcobacter faecis sp. nov., isolated from a human waste septic tank. Syst Appl Microbiol. 2016;39:93-9.

4. Zambri M, Cloutie M, Adam Z, Lapen DR, Wilkes G, Sunohara M, Topp E, Talbot G, Khan IU. Novel virulence, antibiotic resistance and toxin genespecific PCR-based assays for rapid pathogenicity assessment of Arcobacter faecis and Arcobacter lanthieri. BMC Microbiol. 2019;19(11):1-15.

5. Ferreira S, Queiroz JA, Oleastro M, Domingues FC. Insights in the pathogenesis and resistance of Arcobacter: a review. Crit Rev Microbiol. 2016;42(3):364-83

6. Atabay HI, Aydin F, Hou K, Sahin M, Vandamme P. The prevalence of Arcobacter spp. on chicken carcasses sold in retail markets in Turkey, and identification of the isolates using SDS-PAGE. Int J Food Microbiol. 2003;81: 21-8.

7. Collado L, Guarro J, Figueras MJ. Prevalence of Arcobacter in meat and shellfish. J Food Prot. 2009;72(5):1102-6.

8. Villarruel-López A, Márquez-González M, Garay-Martinez LE, Zepeda H, Castillo A, de la Garza LM, Torres-Vitela R. Isolation of Arcobacter spp. from retail meats and cytotoxic effects of isolates against vero cells. J Food Prot. 2003:66(8):1374-8

9. Fera MT, Maugeri TL, Gugliandolo C, Beninati C, Giannone M, La Camera E, Carbone M. Detection of Arcobacter spp. in the coastal environment of the Mediterranean Sea. Appl Environ Microbiol. 2004;70(3):1271-6.

10. Rice EW, Rodgers MR, Wesley IV, Johnson CH, Tanner SA. Isolation of Arcobacter butzleri from ground water. Lett Appl Microbiol. 1999;28:31-5.

11. Collado L, Levican A, Perez J, Figueras MJ. Arcobacter defluvii sp. nov., isolated from sewage samples. Int J Syst Evol Microbiol. 2010;61:2155-61.

12. Houf $K$, Stephan R. Isolation and characterization of the emerging foodborn pathogen Arcobacter from human stool. J Microbiol Methods. 2007;68:40813.

13. van Driessche $E$, Houf $K$, van Hoof J, De Zutter L, Vandamme P. Isolation of Arcobacter species from animal feces. FEMS Microbiol Lett. 2003;229:243-8.

14. van Driessche E, Houf K, Vangroenweghe F, De Zutter L, Van Hoof J. Prevalence, enumeration and strain variation of Arcobacter species in the faeces of healthy cattle in Belgium. Vet Microbiol. 2005;105:149-54.

15. Khan IUH, Cloutier M, Libby M, Lapen DR, Wilkes G, Topp E. Enhanced single-tube multiplex PCR assay for detection and identification of six Arcobacter species. J Appl Microbiol. 2017;123(6):1522-32

16. Diéguez AL, Balboa S, Magnesen T, Romalde JL. Arcobacter lekithochrous sp. nov., isolated from a molluscan hatchery. Int J Syst Evol Microbiol. 2017; 67(5):1327-32

17. Fera MT, Maugeri TL, Gugliandolo C, La Camera E, Lentini V, Favaloro A, Carbone M. Induction and resuscitation of viable nonculturable Arcobacter butzleri cells. Appl Environ Microbiol. 2008;74(10):3266-8.

18. Li L, Mendis N, Trigui H, Oliver JD, Faucher SP. The importance of the viable but non-culturable state in human bacterial pathogens. Front Microbiol. 2014:5:258, https://doi.org/10.3389/fmicb.2014.00258.

19. Abdelbaqi K, Buissonnière A, Prouzet-Mauleon V, Gresser J, Wesley I, Mégraud F, Ménard A. Development of a real-time fluorescence resonance energy transfer PCR to detect Arcobacter species. J Clin Microbiol. 2007; 45(9):3015-21.

20. Brightwell G, Mowat E, Clemens R, Boerema J, Pulford DJ, On SL. Development of a multiplex and real time PCR assay for the specific detection of Arcobacter butzleri and Arcobacter cryaerophilus. J Microbiol Methods. 2007;68:318-25.

21. de Boer RF, Ott A, Güren P, van Zanten E, van Belkum A, Kooistra-Smid AMD. Detection of Campylobacter species and Arcobacter butzleri in stool samples by use of real-time multiplex PCR. J Clin Microbiol. 2013:51(1):253-9.

22. González A, Suski J, Ferrús MA. Rapid and accurate detection of Arcobacter contamination in commercial chicken products and wastewater samples by real-time polymerase chain reaction. Foodborne Path Dis. 2010;7(3):327-38.

23. Girones R, Ferrús MA, Alonso JL, Rodriguez-Manzano J, Calqua B, de Abreu Corrêa A, Bofill-Mas S. Molecular detection of pathogens in water-the pros and cons of molecular techniques. Water Res. 2010:44(15):4325-39.

24. He J-W, Jiang S. Quantification of enterococci and human adenoviruses in environmental samples by real-time PCR. Appl Environ Microbiol. 2005;71(5): 2250-5. 
25. Bellin T, Pulz M, Matussek A, Hempen HG, Gunzer F. Rapid detection of enterohemorrhagic Escherichia coli by real-time PCR with fluorescent hybridization probes. J Clin Microbiol. 2001;39(1):370-4.

26. Sails AD, Fox AJ, Bolton FJ, Wareing DRA, Greenway DLA. A real-time PCR assay for the detection of Campylobacter jejuni in foods after enrichment culture. Appl Environ Microbiol. 2003;69(3):1383-90.

27. Wilkes G, Brassard J, Edge TA, Gannon V, Gottschall N, Jokinen CC, Jones TH, Khan IUH, Marti R, Sunohara MD, Topp E. Long-term monitoring of waterborne pathogens and microbial source tracking markers in paired agricultural watersheds under controlled and conventional tile drainage management. Appl Environ Microbiol. 2014;80(12):3708-20.

28. Chen W, Wilkes G, Khan IUH, Pintar KDM, Thomas JL, Lévesque CA, Lapen DR. Aquatic bacterial communities associated with land use and environmental factors in agricultural landscapes using a metabarcoding approach. Front Microbiol. 2018;9:2301.

29. Levican A, Alkeskas A, Günter C, Forsythe SJ, Figueras MJ. Adherence to and invasion of human intestinal cells by Arcobacter species and their virulence genotypes. Appl Environ Microbiol. 2013;79(16):4951-7.

30. Shrestha RG, Tanaka Y, Malla B, Tandukar S, Bhandari D, Inoue D, Sei K, Sherchand JB, Haramoto E. Development of a quantitative PCR assay for Arcobacter spp. and its application to environmental water samples. Microbes Environ. 2018;33(3):309-16. https://doi.org/10.1264/jsme2. ME18052

31. Edge TA, El-Shaarawi A, Gannon V, Jokinen C, Kent R, Khan IUH, Koning W, Lapen D, Miller J, Neumann N, Phillips R. Investigation of an Escherichia coli environmental benchmark for waterborne pathogens in agricultural watersheds in Canada. J Environ Qual. 2012;41(1):21-30.

32. Lyautey E, Lu Z, Lapen DR, Wilkes G, Scott A, Berkers T, Topp E. Distribution and diversity of Escherichia coli populations in the South Nation River drainage basin, eastern Ontario, Canada. Appl Environ Microbiol. 2010;6(5): 1486-96.

33. Marti R, Gannon VPJ, Jokinen C, Lanthier M, Lapen DR, Neumann NF, Topp E. Quantitative multi-year elucidation of fecal sources of waterborne pathogen contamination in the South Nation River basin using Bacteroidales microbial source tracking markers. Water Res. 2013:47:2315-24.

34. Lyautey E, Lapen DR, Wilkes G, McCleary K, Pagotto F, Tyler K, Topp E. Distribution and characteristics of Listeria monocytogenes isolates from surface waters of the south Nation River watershed, Ontario, Canada. Appl Environ Microbiol. 2007;73(17):5401-10.

35. Frey SK, Topp E, Edge T, Fall C, Gannon V, Jokinen C, Marti R, Neumann N, Ruecker N, Wilkes G, Lapen DR. Using SWAT, Bacteroidales microbial source tracking markers, and fecal indicator bacteria to predict waterborne pathogen occurrence in an agricultural watershed. Water Res. 2013;47(16): 6326-37.

36. Khan IUH, Hill S, Nowak E, Palme ME, Jarjanazi H, Lee D-Y, Mueller M, Schop R, Weir S, Abbey A, Winter J, Edge TA. Investigation of the prevalence of thermophilic Campylobacter species at Lake Simcoe recreational beaches. Inland Waters. 2013:3(1):93-104

37. Wilkes G, Ruecker NJ, Neumann NF, Gannon VP, Jokinen C, Sunohara M, Topp E, Pintar KD, Edge TA, Lapen DR. Spatiotemporal analysis of Cryptosporidium species/genotypes and relationships with other zoonotic pathogens in surface water from mixed-use watersheds. Appl Environ Microbiol. 2013;79(2):434-48.

38. Wilkes G, Edge TA, Gannon VPJ, Jokinen C, Lyautey E, Neumann NF, Lapen DR. Associations among pathogenic bacteria, parasites, and environmental and land use factors in multiple mixed-use watersheds. Water Res. 2011; 45(18):5807-25.

39. Lapen DR, Schmidt PJ, Thomas JL, Edge TA, Flemming C, Keithlin J, Neumann N, Pollari F, Ruecker N, Simhon A, Topp E. Towards a more accurate quantitative assessment of seasonal Cryptosporidium infection risks in surface waters using species and genotype information. Water Res. 2016; 105:625-37.

40. StatSoft, Inc. Electronic statistics textbook. Tulsa: StatSoft:; 2013. https://www. statsoft.com/textbook.

\section{Publisher's Note}

Springer Nature remains neutral with regard to jurisdictional claims in published maps and institutional affiliations.

\section{Ready to submit your research? Choose BMC and benefit from}

- fast, convenient online submission

- thorough peer review by experienced researchers in your field

- rapid publication on acceptance

- support for research data, including large and complex data types

- gold Open Access which fosters wider collaboration and increased citations

- maximum visibility for your research: over $100 \mathrm{M}$ website views per year

At BMC, research is always in progress.

Learn more biomedcentral.com/submissions 